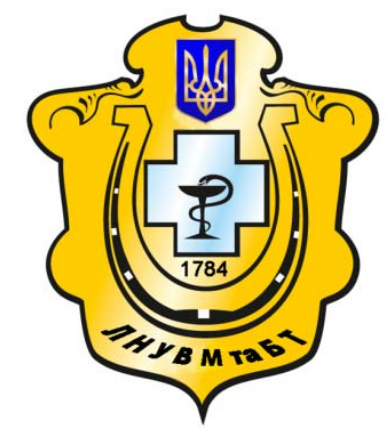

Науковий вісник Львівського національного університету ветеринарної медицини та біотехнологій імені С.З. Гжицького

Scientific Messenger of Lviv National University of Veterinary Medicine and Biotechnologies named after S.Z. Gzhytskyj

doi:10.15421/nvlvet7510

ISSN 2519-268X print

ISSN 2518-1327 online

$\underline{\text { http://nvlvet.com.ua/ }}$

УДК 577.112.083/122.2

\title{
Отримання казеїнових фосфопептидів за дії протеолітичних систем лактококів
}

\author{
В.Г. Юкало, Л.А. Сторож \\ biotech@tu.edu.te.ua \\ Тернопільський національний технічний університет імені Івана Пулюя, \\ вул. Руська, 56, м. Тернопіль, 46001, Украӥна
}

\begin{abstract}
Протеїни молока, зокрема протеїни казеїнового комплексу, є попередниками біологічно активних пептидів. Ці пептиди утворюються в процесі розщеплення казеїнів травними протеазами у шлунково-кишковому тракті. Також вони можуть звільнятися під час технологічних процесів виробництва молочних продуктів за дії молокозгортальних препаратів та ензимів протеолітичних систем молочнокислих бактерій. Одними із найважливіших біологічно активних пептидів, які утворюються з казеїнів, є фосфопептиди. Вони позитивно впливають на засвоєння кальцію та інших двовалентних іонів металів. Для отримання фосфопептидів із казеїну використовують активні протеолітичні препарати тваринного, рослинного $i$ мікробіологічного походження. Не з'ясованим залишається питання можливості утворення фосфопептидів за дії протеаз молочнокислих бактерій, зокрема лактококів, які поширені в молочі та молочних продуктах. Метою нашої роботи було встановити можливість утворення казеӥнових фосфопептидів за дії ензимів протеїназа-позитивних протеолітично активних лактококів. Для досліджень була використана протеолітична система, яка дозволила збільшити активність протеаз лактококів. Були відібрані три штами протеїназа-позитивних протеолітично активних лактококів різних підвидів. Як субстрати були виділені загальний кислотний казеӥн, нативний міцелярний казеӥн, суміш фракцій $\alpha_{S I^{-}}-C N i \alpha_{S 2}-C N, \beta$-CN. $У$ всіх випадках вихід фосфопептидів не перевищував 3\%. Такий вихід є занадто низьким для виробництва фосфопептидів, але може мати значення при їх утворенні у ферментованих молочних продуктах.

Ключові слова: фосфопептиди, казеїн, лактококи, протеоліз.
\end{abstract}

\section{Получение казеиновых фосфопептидов под действием протеолитических систем лактококков}

\author{
В.Г. Юкало, Л.А. Сторож \\ biotech@tu.edu.te.ua
}

Тернопольский национальный технический университет имени Ивана Пулюя,

ул. Русская, 56, г. Тернополь, 46001, Украина

\begin{abstract}
Протеины молока, в частности протеины казеинового комплекса, являются предшественниками биологически активныхх пептидов. Эти пептиды образуются в процессе расщепления казеина пищеварительныли протеазами в желудочнокишечном тракте. Также они могут освобождаться при технологических прочессах производства молочных продуктов под действием молокосвертывающих препаратов и ферментов протеолитических систем молочнокислых бактерий. Одними из важнейших биологически активных пептидов, которые образуются из казеина, являются фосфопептиды. Они положстельно влияют на усвоение кальиия и других двухвалентных ионов металлов. Для получения фосфопептидов с казеина используют активные протеолитические препараты животного, растительного и микробиологического происхождения. Невыясненным остается вопрос о возможности образования фосфопептидов под действием протеаз молочнокислых бактерий, в частности лактококков, которые распространены в молоке и молочных продуктах. Целью нашей работы было установить возможность образования казеиновых фосфопептидов под действием энзимов протеиназаположительных протеолитически активных лактококков. Для исследований была использована протеолитическая систе-
\end{abstract}

Citation:

Yukalo, V.G., Storozh, L.A. (2017). Obtaining of casein phosphopeptides under the influence of proteolytic systems of Lactococci. Scientific Messenger LNUVMBT named after S.Z. Gzhytskyj, 19(75), 50-54. 
ма, которая позволила увеличить активность протеаз лактококков. Были отобраны три итамма протеиназаположительных протеолитически активных лактококков разных подвидов. Как субстраты были выделены общий кислотный казеин, нативный мицеллярный казеин, смесь фракциий $\alpha_{S 1}-C N$ и $\alpha_{S 2}-C N, \beta$-CN. Во всех случаях выход фосфопептидов не превышал 3\%. Такой выход слишком низкий для производства фосфопептидов, но может иметь значение при их образовании в ферментированных молочных продуктах.

Ключевые слова: фосфопептиды, казеин, лактококки, протеолиз.

\title{
Obtaining of casein phosphopeptides under the influence of proteolytic systems of Lactococci
}

\author{
V.G. Yukalo, L.A. Storozh \\ biotech@tu.edu.te.ua \\ Ternopil National Technical University Ivan Pul'uj, \\ Ruska Str., 56, Ternopil, 46001, Ukraine
}

\begin{abstract}
Milk proteins, particularly casein complex proteins, are precursors of biologically active peptides. These peptides are formed during the cleavage of caseins by digestive proteases in the gastrointestinal tract. They can also be released during the technological processes of production of dairy products under the influence of milkclotting preparations and enzymes of proteolytic system of lactic acid bacteria. One of the most important bioactive peptides formed of casein, is phosphopeptide. Phosphopeptides positively affect the absorption of calcium and other divalent metal ions. To get phosphopeptides from casein active proteolytic preparations of animal, plant and microbiological origin are used. The possibility of formation of phosphopeptides under the influence of lactic acid bacteria proteases, in particular lactococci that are common in milk and dairy products had not been clarified. The aim of our study was to establish the possibility of formation casein phosphopeptides under the influence of proteinase-positive proteolytically active lactococcus' enzymes. Proteolytic system which allowed increasing the activity of lactococcus proteases was used for research. Three strains of proteinase positive proteolytically active lactococci different subspecies were selected. The total acid casein, native micellar casein, the amount of fractions $\sigma_{S 1}-C N$ and $\sigma_{S 2}-C N,{ }_{6}-C N$ were identified as substrates. It has been established that both preparations of total casein split better under the influence of selected lactococci strains. However, at the beginning of proteolysis the intensity of splitting was slightly higher for undenatured micellar casein compared to the acid casein. Fractions $\alpha_{S}-C N-X P i$ $\beta-C N-5 P$ were less sensitive to proteolytic system of lactococcus. After three hours of incubation, the selection of phopsphopeptides has been implemented. In all cases, their output did not exceed 3\%. Such output is too low for phopsphopeptides production but may be important for their formation in fermented dairy products.
\end{abstract}

Key words: phosphopeptides, casein, lactococci, proteolysis.

\section{Вступ}

Лактококи для забезпечення свого розвитку в молоці використовують в першу чергу вільні амінокислоти та компоненти протеозо-пептонної фракції. Далі розвиток протеїназа-негативних штамів припиняється. Протеїназа-позитивні штами здатні розщеплювати протеїни молока і продовжувати свій розвиток завдяки послідовній дії ензимів протеолітичної системи: приклітинних протеїназ, мембранних і внутрішньоклітинних протеїназ та пептидаз. Окремі штами лактококів характеризуються високою загальною протеолітичною активністю, а їхні приклітинні протеїнази мають широку специфічність дії по відношенню до протеїнів казеїнового комплексу. Показано, що приклітинна протеїназа лактококів лише $\beta$-казеїн може розщеплювати з утворенням більше сотні різних пептидів (Juillard et al., 1995).

На сьогоднішній день встановлено, що в процесі протеолізу протеїнів казеїнового комплексу утворюється велика кількість пептидів 3 різними видами біологічної активності. Одними 3 найважливіших $є$ казофосфопептиди, які відіграють суттєву роль у забезпеченні організму іонами кальцію та іншими двовалентними іонами металів (Yukalo et al., 2012). Нами раніше були охарактеризовані протеїназапозитивні штами лактококів Lactococcus lactis subsp. lactis, Lactococcus lactis subsp. cremoris i Lactococcus lactis biovar. diacetylactis та відібрані штами з найбі- льшою протеолітичною активністю (Yukalo and Storozh, 2011). Такі штами, очевидно, можуть призводити до звільнення фосфопептидів при використанні протеїнів казеїнового комплексу в процесі протеїнового живлення.

Метою роботи було встановити можливість утворення казофосфопептидів за дії ензимів протеїназапозитивних протеолітично активних лактококів.

\section{Матеріал і методи досліджень}

Для дослідження було відібрано стійкі протеолітично активні штами $1_{12}$ (Lactococcus lactis subsp. lactis), $\mathrm{c}_{4}$ (Lactococcus lactis subsp. cremoris) i $\mathrm{d}_{7}$ (Lactococcus lactis biovar. diacetylactis), які культивуються на кафедрі харчової біотехнології і хімії Тернопільського національного технічного університету імені Івана Пулюя. Штами підтримували шляхом пересівання у знежирене стерилізоване молоко через кожні 20 днів.

Протеолітичну активність лактококів визначали методом Гула в модифікації Залашка M.B. (Zalashko et al., 1970). В основі методу - реакція реактиву Фоліна із залишками тирозину та триптофану продуктів протеолізу казеїну. Оптичну густину забарвлених продуктів протеолізу визначали спектрофотометрично при довжині хвилі 650 нм.

Як субстрати використовували загальний казеїн, який виділяли із свіжого молока подвійним переосадженням в ізоелектричній точці, та міцелярний казеїн, 
який отримували при розшаруванні системи «протеїн - кислий полісахарид - вода» в умовах термодинамічної несумісності компонентів (Yukalo, 2005). Iз загального казеїну виділяли суміш фракцій $\alpha_{\mathrm{S} 1-\mathrm{CN}}$ i $\alpha_{\mathrm{S} 2-}$ $\mathrm{CN}$ шляхом диференційного осадження. Розділення $\alpha_{\mathrm{S}}-\mathrm{CN}$ і $\beta$-CN фракцій проводили 3 врахуванням відмінностей в їх розчинності в присутності сечовини при значеннях $\mathrm{pH}$ близько 4,6 (Yukalo and Storozh, 2010).

Концентрацію протеїнів у препаратах визначали за поглинанням при довжині хвилі 280 нм на спектрофотометрі СФ-46. При цьому використовували загальноприйняті коефіцієнти поглинання: 10,0 - для $\alpha_{\mathrm{S1}_{1}}$ $\mathrm{CN} ; 10,1$ - для $\alpha_{\mathrm{S} 2}-\mathrm{CN} ; 4,6$ - для $\beta$-CN i 8,2 - для загального казеїну.

Фосфопептиди із гідролізатів виділяли осадженням солями кальцію в присутності етанолу, як описано раніше (Yukalo and Storozh, 2013).

В роботі на графіках наведено середні значення, отримані в результаті п'яти вимірювань. Математично-статистичий аналіз виходу фосфопептидів проводили з використанням програми Microsoft Office Excel 2003.

\section{Результати та їх обговорення}

Для проведення досліджень 3 метою отримання фосфопептидів були відібрані стійкі протеолітично активні штами $\mathrm{l}_{12}, \mathrm{c}_{4}, \mathrm{~d}_{7}$. Очищену біомасу, яку використовували для протеолізу фосфопротеїнів, отримували за методикою вирощування лактококів у знежиреному молоці в присутності $\beta$-гліцерофосфату (Yukalo, 2006). При цьому, як було показано раніше новозеландськими вченими Т. Томасом і О. Мілсом, молочнокислі лактококи зберігають свої протеолітичні системи, в тому числі і приклітинні протеїнази. Нарощування біомаси відібраних штамів проводили за схемою, вказаною на рис. 1.

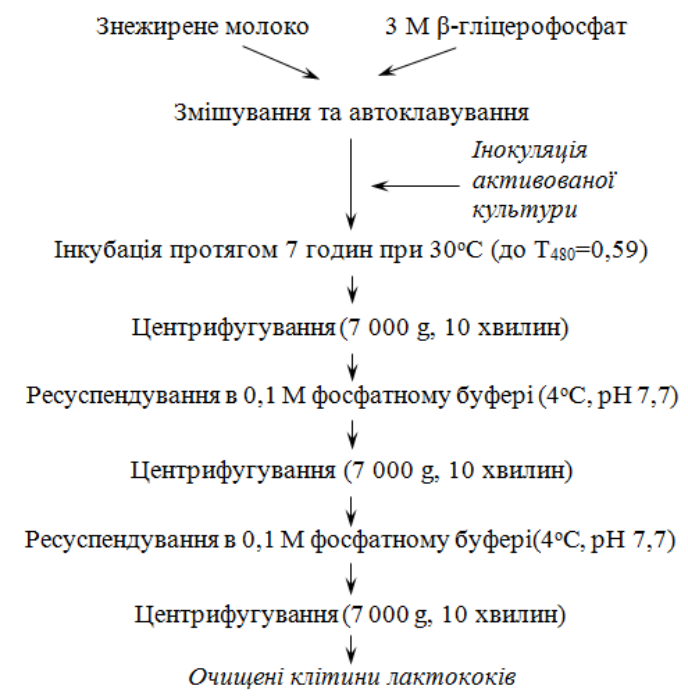

Рис. 1. Схема нарощування біомаси лактококів у присутності $\beta$-гліцерофосфату

Отримані таким чином очищені клітини лактококів використовували для протеолізу фосфопротеїнових субстратів. Інкубування проводили у термостаті при температурі $30{ }^{\circ} \mathrm{C}$. Значення $\mathrm{pH}$ підтримували на рівні 5,5. До 18 мл 2\% фосфопротеїнового субстрату в $0,05 \mathrm{M}$ ацетатному буфері (рН 5,5) вносили 2 мл біомаси лактококів, отриманої в молочному середовищі у присутності $\beta$-гліцерофосфату (рис. 1). Ступінь протеолізу оцінювали через кожні 60 хвилин протягом 3 годин. При цьому з реакційної суміші відбирали по 3 мл гідролізату, додавали по 3 мл 10\% трихлороцтової кислоти. Осад нерозщеплених протеїнів відфільтровували. Розчинні продукти протеолізу розводили в десять разів 5\% оцтовою кислотою і вимірювали оптичну густину на спектрофотометрі СФ-46 при довжині хвилі 280 нм. Для отримання об'єктивних результатів ми припустили, що продукти протеолізу кожної фракції мають такі ж коефіцієнти поглинання, як і самі фракції. А саме, загальний препарат фосфопротеїнів і його гідролізат - 8,2; $\beta$-CN-5P і його гідролізат - 4,6; для суміші $\alpha_{\mathrm{S} 1}-\mathrm{CN}-\mathrm{XP}$ і $\alpha_{\mathrm{S} 2}-\mathrm{CN}-\mathrm{XP}$ та $\dddot{11}$ гідролізатів, враховуючи співвідношення цих фракцій, для розрахунків вибрали значення 10,0. Було зроблено наступні перерахунки: $\mathrm{E}_{280}$ для загального препарату фосфопротеїнів залишали без змін; $\mathrm{E}_{280}$ для $\beta-\mathrm{CN}-5 \mathrm{P}$ перемножували на 1,$78 ; \mathrm{E}_{280}$ для $\alpha_{\mathrm{S}}-\mathrm{CN}-\mathrm{XP}$ перемножували на 0,82 . Отримані результати щодо ходу протеолізу представлено у вигляді графіків на рис. 2, 3 і 4 на основі середніх значень п'яти вимірювань.

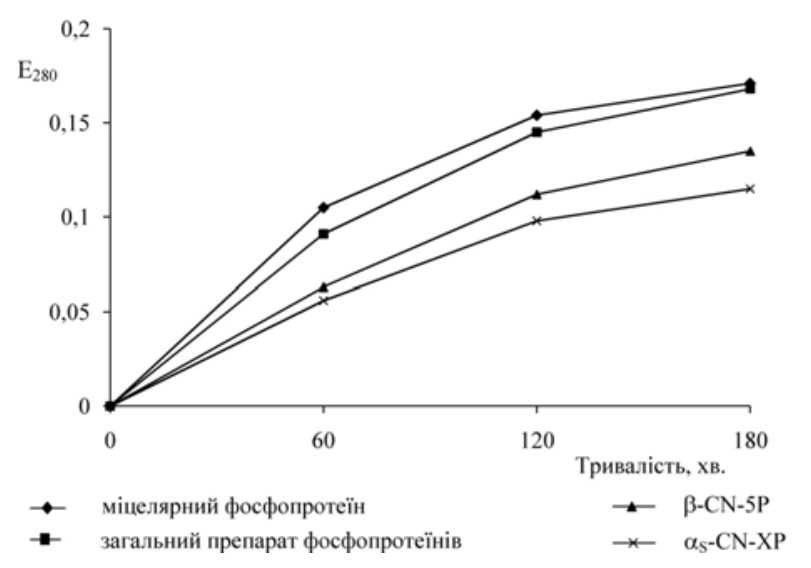

Рис. 2. Протеоліз фосфопротеїнових субстратів лактококами підвиду Lactococcus lactis subsp. lactis (IIтам $l_{12}$ )

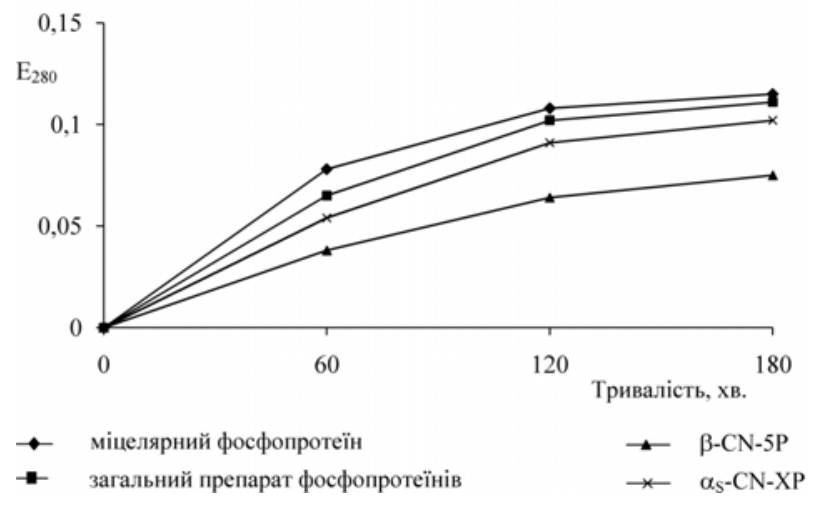

Рис. 3. Протеоліз фосфопротеїнових субстратів лактококами підвиду Lactococcus lactis subsp.cremoris (штам $c_{4}$ ) 


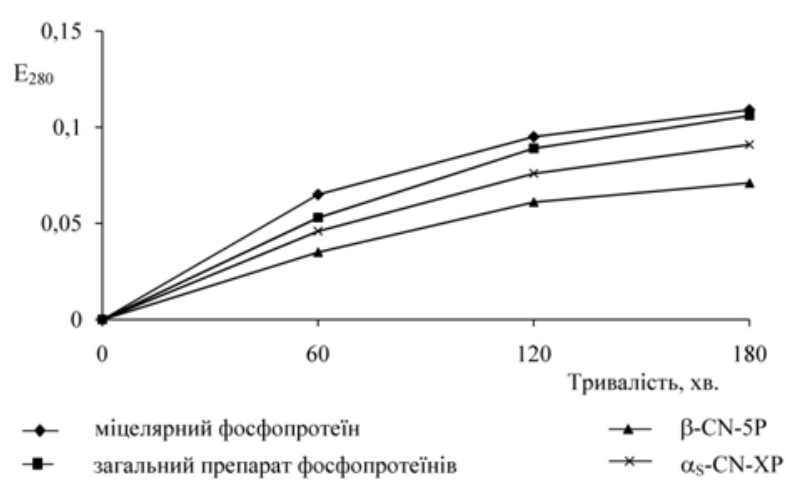

Рис. 4. Протеоліз фосфопротеїнових субстратів лактококами підвиду Lactococcus lactis biovar. diacetylactis (штам $d_{7}$ )

На графіках можна побачити відмінності в інтенсивності протеолізу фосфопротеїнових субстратів вибраними штамами лактококів. Найвищу активність показав штам $1_{12}$ підвиду Lactococcus lactis subsp. lactis. В усіх випадках інтенсивно розщеплювалися препарати загального фосфопротеїну. Міцелярний препарат неденатурованих фосфопротеїнів показав близькі значення до кислотного загального препарату фосфопротеїнів. Причому, на початку протеолізу інтенсивність його розщеплення була дещо вищою, що в певній мірі узгоджується 3 твердженнями М. Чернікова про більшу доступність неденатурованих молочних протеїнів до дії травних протеаз (Chernikov, 1975). Але на пізніших етапах протеолізу суттєвих відмінностей в інтенсивності розщеплення обох препаратів загального фосфопротеїну за дії протеаз лактококів не спостерігалося. Що ж стосується субстратів $\alpha_{\mathrm{S}}-\mathrm{CN}-\mathrm{XP}$ і $\beta-\mathrm{CN}-5 \mathrm{P}$, то вони виявилися менш чутливими до дії протеолітичної системи лактококів. Разом $з$ тим, фосфопротеїн $\beta-\mathrm{CN}-5 \mathrm{P}$ краще розщеплювався при інкубації зі штамом $l_{12}$ підвиду Lactococcus lactis subsp. lactis. До протеаз штамів $c_{4}$ підвиду Lactococcus lactis subsp. cremoris та $d_{7}$ підвиду Lactococcus lactis biovar. diacetylactis чутливішими були фосфопротеїни суміші $\alpha_{\mathrm{S}}-\mathrm{CN}-\mathrm{XP}$.

Після трьох годин інкубування відбирали проби для виділення фосфопептидів. Значення рН гідролізату доводили 1 Н хлоридною кислотою до 4,6 для осадження нерозщеплених протеїнів, які потім відділяли центрифугуванням. До 9 мл отриманої надосадової рідини, яка містила продукти протеолізу, додавали 1 мл $10 \% \mathrm{CaCl}_{2}$ і 10 мл етанолу. Осад фосфопептидів отримували центрифугуванням, промивали етанолом, висушували до постійної маси і зважували. Дані зважування наведені у табл. 1. Результати отримано на основі п'яти повторностей з кожною із комбінацій.

Для обох препаратів загального фосфопротеїну, а також очищеного фосфопротеїну $\beta-\mathrm{CN}-5 \mathrm{P}$ вихід фосфопептидів більшим був при використанні клітин штаму $1_{12}$. У випадку суміші фосфопротеїнів $\alpha_{\mathrm{S}}-\mathrm{CN}$ $\mathrm{XP}$, при інкубуванні іiі зі штамом $\mathrm{l}_{12}$ вихід був менший, ніж зі штамами $\mathrm{c}_{4} \mathrm{Ta}_{\mathrm{f}}$. Для всіх фосфопротеїнових субстратів вихід фосфопептидів був низький і не перевищував 3\%. Це може мати значення при утворенні фосфопептидів у ферментованих молочних продуктах, але для виділення препаратів фосфопептидів такий вихід занадто низький і процес не є оправданим. При виробництві ферментованих молочних продуктів може проводитися селекція штамів молочнокислих бактерій для отримання біологічно активних пептидів, зокрема фосфопептидів. Так, французькими вченими (Algaron et al., 2004) методами генної інженерії були сконструйовані штами, які дозволяють збільшити вихід фосфопептидів з протеїнів молока при виробництві ферментованих молочних продуктів.

Вихід фосфопептидів після протеолізу фосфопротеїнових субстратів протеїназа-позитивними штамами лактококів (M $\pm \mathbf{m}, \mathbf{n}=\mathbf{5})$

\begin{tabular}{|c|c|c|c|c|c|c|c|c|}
\hline \multirow{2}{*}{ Штам } & \multicolumn{9}{|c|}{ Субстрат } & \multicolumn{2}{|c|}{$\beta$-СN-5P } \\
\cline { 2 - 8 } & \multicolumn{2}{|c|}{$\begin{array}{c}\text { загальний препарат } \\
\text { фосфопротёнів }\end{array}$} & $\begin{array}{c}\text { міцелярний фосфопро- } \\
\text { теїн }\end{array}$ & \multicolumn{2}{|c|}{$\alpha_{\mathrm{S}}$-CN-ХР } \\
\cline { 2 - 8 } & $\begin{array}{c}\text { к-ть фосфо- } \\
\text { петидів, } \\
\text { мг }\end{array}$ & $\begin{array}{c}\text { вихід, } \\
\%\end{array}$ & $\begin{array}{c}\text { к-ть фосфо- } \\
\text { пептидів, } \\
\text { мг }\end{array}$ & $\begin{array}{c}\text { вихід, } \\
\%\end{array}$ & $\begin{array}{c}\text { к-ть фосфо- } \\
\text { пептидів, } \\
\text { мг }\end{array}$ & $\begin{array}{c}\text { вихід, } \\
\%\end{array}$ & $\begin{array}{c}\text { к-ть фосфо- } \\
\text { пептидів, } \\
\text { мг }\end{array}$ & $\begin{array}{c}\text { вихід } \\
\%\end{array}$ \\
\hline $\begin{array}{c}\text { Lactococcus } \\
\text { lactis subsp. } \\
\text { Lactis }\left(l_{12}\right)\end{array}$ & $2,7 \pm 0,2$ & 1,50 & $2,5 \pm 0,2$ & 1,39 & $1,5 \pm 0,1$ & 0,83 & $1,6 \pm 0,2$ & 0,89 \\
\hline $\begin{array}{c}\text { Lactococcus } \\
\text { lactis subsp. } \\
\text { Cremoris }\left(c_{4}\right)\end{array}$ & $2,3 \pm 0,1$ & 1,28 & $2,3 \pm 0,2$ & 1,28 & $1,9 \pm 0,2$ & 1,06 & $1,3 \pm 0,1$ & 0,72 \\
\hline $\begin{array}{c}\text { Lactococcus } \\
\text { lactis biovar. } \\
\text { diacetylactis }\left(d_{7}\right)\end{array}$ & $1,9 \pm 0,1$ & 1,06 & $2,0 \pm 0,1$ & 1,11 & $1,8 \pm 0,1$ & 1,00 & $1,4 \pm 0,1$ & 0,78 \\
\hline
\end{tabular}

\section{Висновки}

При отриманні фосфопептидів 3 використанням протеїназа-позитивних протеолітично активних штамів лактококів і чотирьох видів фосфопротеїнових субстратів (загальний кислотний казеїн, нативний міцелярний казеїн, суміш $\alpha_{\mathrm{S} 1}-\mathrm{CN}$ i $\left.\alpha_{\mathrm{S} 2}-\mathrm{CN}, \beta-\mathrm{CN}\right)$ у всіх випадках вихід був низьким і не перевищував $3 \%$. Такий вихід є занадто низьким для виробництва фосфопептидів, але може мати значення при їх утворенні у ферментованих молочних продуктах. 
Перспективи подальших досліджень. У подальшій роботі потрібно відібрати молочнокислі палички, протеолітична активність яких вища порівняно з лактококами. Вони можуть бути використані для отримання більшої кількості фосфопептидів і створення функціональних харчових продуктів.

\section{Бібліографічні посилання}

Juillard, V., Laan, H., Kunji, E.R. (1995). The extracellular $\mathrm{P}_{\mathrm{I}}$-type proteinase of Lactococcus lactis hydrolyzes $\beta$-casein into more than one hundred different oligopeptides. J. Bacteriol. 177(12), 3472-3478.

Yukalo, A.V., Storozh, L.A., Yukalo, V.H. (2012). Proteiny kazeinovoho kompleksu moloka koriv (Bos taurus) yak poperednyky biolohichno aktyvnykh peptydiv. Biotekhnolohiia. 5(4), 21-33 (in Ukrainian).

Yukalo, V.H., Storozh, L.A. (2011). Proteoliz riznykh frakzii kazeinu fermentnymy systemamy laktokokiv. Kharchova promyslovist. 10, 144-148 (in Ukrainian).

Zalashko, M.V., Obraztsova, N.V., Savchenko, E.I. (1970). Issliedovaniie proteoliticheskoi aktivnosti molochnokislykh baktierii. Fiziologiia i biokhimiia mikroorganizmov. Minsk: Nauka i tiekhnika, 121-128 (in Russian).

Yukalo, V.G. (2005). Obtaining of casein protein complex fractions from cow milk. Nutracos. 5, 17-19.

Yukalo, V.H., Storozh, L.A. (2010). Vydilennia sumishi $\alpha_{\mathrm{S}}$-kazeiniv koroviachoho moloka dlia otrymannia bioaktyvnykh peptydiv. Naukovi pratsi NUKHT. 33, 58-60 (in Ukrainian).

Yukalo, V., Storozh, L. (2013). The isolation of phosphopeptides from total casein and its fractions. Food chemistry and technology. 47(2), 32-40.

Yukalo, V.H. (2006). Modelna proteolitychna systema dlia vydilennia bioaktyvnykh peptydiv $\mathrm{z}$ bilkiv kazeinovoho kompleksu. Materialy IX Ukrainskoho biokhimichnoho zyizdu. Kyiv: IB NAN Ukrainy (in Ukrainian).

Chernikov, M.P. (1975). Proteoliz i biologichieskaia tsennost bielkov (kazeiny kak sobstvienno pishchievyie bielky). M.: Mieditsina (in Russian).

Algaron, F., Miranda, G., Le Bars, D., Monnet, V. (2004). Milk fermentation by Lactococcus lactis with modified proteolytic systems to accumulate potentially bio-active peptides. Lait. 84, 115-123.

Стаття надійшла до редакиї 6.02.2017 